\title{
ISSUES IN BALTO-SLAVIC ACCENTOLOGY
}

\author{
FREDERIK KORTLANDT
}

After the very well-organized Leiden conference for which we must be grateful to Tijmen Pronk, it seems appropriate for me to review some of the papers, as I did after the previous conferences in Zagreb and Copenhagen. The aim of this review is merely to point out some of the differences of opinion which require further debate.

Mislav Benić presents a detailed description of verbal accentuation in the dialect of Kukljica on the island of Ugljan. The dialect has no tonal distinctions but does have vowel quantity in stressed and pretonic syllables, with large-scale lengthening of short vowels under the stress. It has preserved the Common Slavic distinction between original pretonic long vowels, which were shortened as a result of the rise of the new timbre differences, and new pretonic long vowels which arose as a result of Dybo's law (cf. Kortlandt 2005: 126-128), e.g. jazik 'tongue' (with secondary lengthening of the stressed vowel) versus nạröd 'people'. It has also preserved the distinction between simplex verbs with mobile stress, e.g. budin 'wake up', gasin 'turn off, and compound verbs where the prefix lost the stress to the root in accordance with Dybo's law, e.g. prebûdin, ugäsin (ibidem, 127). Moreover, it has preserved the accentual mobility of the original nasal present in në znon 'don't know' (cf. Kortlandt 1985) and the re-

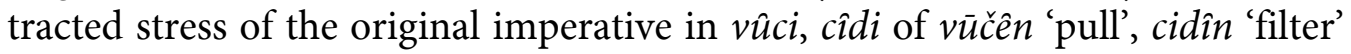
(cf. Kortlandt 1979: 53).

Miguel Carrasquer Vidal proposes a derivation of acute and circumflex tones from the syllable structure of the proto-language. His account involves tones on unstressed syllables, resyllabifications, analogical replacements, ad hoc rules for different stem formations and for different languages, secondary developments, unexplained exceptions for which he posits a PIE distinction between ${ }^{\star} i$ and ${ }^{\star} j$, and structural ambiguity of the postvocalic ending ${ }^{*}-n s$. He lists a number of Slavic Auslautgesetze in order to arrive at the correct output. Since I have discussed all of the issues elsewhere, I shall not return to the many points of disaggreement here.

Vladimir Dybo compares the West Caucasian, Balto-Slavic and Japanese accent systems in terms of "dominant" and "recessive" morphemes expressed in syllables and contours. In my review of last year's conference in Copenhagen, I have shown how the class of dominant suffixes originated from several retrac- 
tions of the stress in Balto-Slavic. Unlike Japanese, where the extant accent systems go back to reductions of a system with a distinction between high and low tone in every syllable (cf. Kortlandt 1993), the systems attested in Balto-Slavic developed from a prosodic system which strongly resembles what we find in Vedic Sanskrit. In another contribution, Dybo subscribes to my analysis of the Old Prussian accentual system (1974), concentrating on the verb, the stem formation of which I have discussed elsewhere (1987).

Ronald Feldstein is primarily concerned with the more recent development of nominal accent patterns in West Slavic. He claims that the long vowels of Czech kráva 'cow' and brázda 'furrow' have retained length in stressed and pretonic position, respectively, while the short vowel of strana 'side' was taken from the acc.sg. form stranu. In fact, the long vowel of kráva resulted from recent lengthening of a short rising vowel (cf. Kortlandt 2005: 125, 2006a: 32), the long vowel of brázda became pretonic as a result of Dybo's law, and the original pretonic long vowel of strana was regularly shortened when the new timbre distinctions arose (cf. Kortlandt 2005: 126, 2006a: $36 f$.). The short vowel of ${ }^{\star} k r a ̀ v a$ was never lengthened in the oblique forms krav, kravám, kravách, kravami, Slovak krava, SCr. kräva, Polish krowa < ${ }^{\star} k r o ̀ w a$, but Upper Sorbian kruwa < krówa with the same lengthening as in Czech kráva, vưle, kưže, which was clearly more recent than the rise of the new timbre distinctions. As a result, we find length in accent paradigm (b), absence of length in (c), and alternation between long and short vowels in (a). The original distribution was blurred by secondary lengthening before word-final voiced fricatives and resonants and by paradigmatic generalizations.

Georg Holzer defines "Urslavisch" as the last stage of prehistoric Slavic before the earliest dialectal differentiation. This corresponds to the end of my Early Middle Slavic and the beginning of my Late Middle Slavic period (e.g., 2005: 120, 2006a: 27). Holzer reconstructs the following prosodic characteristics for this stage:

(1) He posits the existence of "betonungslos" word forms, e.g. Ru. storonu 'side' in ná storonu and SCr. pripovijest 'story' in nä pripovijest. Unfortunately, he remains silent about the accentuation of these nouns when there is no preposition to take the accent (cf. Kortlandt 1978: 72-76 and 2006b: $360 f$. for discussion). He compares them with "betonungslos" word forms in Vedic Sanskrit, which are actually characterized by distinctive low tones (cf. Kortlandt 1986: 156). In order to simplify the discussion, I shall therefore assume that "betonungslos" stands for "having low tones only".

(2) Holzer dates Meillet's law "im Nachurslavischen" because of the pretonic lengthening in Ukr. ratáj 'ploughman'. However, this accentuation is clearly secondary, cf. Ru. rátaj, Bulg. rátaj, Slovene rátaj, SCr. rätār, all pointing to fixed stress on the initial syllable. Similarly, the accent of Ru. ramjáno 'very' 
must be secondary in view of Slovene rámeno while the accent of the secondary derivative lanita 'cheek' does not prove anything. Czech lan̆ 'hind' evidently represents accent pattern (a), as is clear from Slovene lânjac.

(3) Holzer maintains that all original long vowels were still long, which is correct in the sense that the rise of the new timbre distinctions belongs to the Late Middle Slavic period. However, the monophthongization of diphthongs belongs to the Early Middle Slavic period and is not "nachurslavisch", contrary to his statement (cf. Kortlandt 2006a: 33f.).

(4) Holzer correctly dates Dybo's law "im Nachurslavischen”. His unification of "AP a und b" into "ein einziges AP a" cannot be recommended because it can easily lead to confusion.

(5) "Das Urslavische hatte noch keinen Neoakut". This statement is correct in the sense that the retractions of the stress from which new rising vowels originated can be dated after the rise of the new timbre distinctions. However, the origin of non-acute rising vowels must be dated to the end of the Early Middle Slavic period.

(6) Hirt's law must be dated to the Balto-Slavic period (cf. Kortlandt 2005: 116f.). Following Illič-Svityč's original formulation (1963: 81f.), Holzer assumes that the accent was not retracted from an acute syllable. This limitation, which is not supported by independent evidence, is at variance with the regular character of the retraction in the $a H$-stems, e.g. SCr. grìva 'mane', and must therefore be rejected. Accentual mobility was preserved in the Slavic $i$ - and $u$-stems, e.g. SCr. klïjet 'shed', sin 'son', where polysyllabic case forms predominated in the paradigm.

(7) Holzer assumes that a word-initial high tone was lost in two-syllable words ending in ${ }^{*}$-as $<{ }^{*}$-os, yielding a separate accent pattern (d), e.g. in SCr.

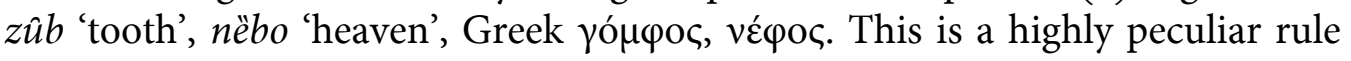
which cannot be correct (cf. Kortlandt 2006a: 33).

(8) Antevocalic laryngeals were lost in Early Slavic, as is clear from Ru. soxá 'plough', Lith. šakà 'branch'. Syllabic ${ }^{\star} H i$ and ${ }^{\star} H u$ yielded acute vowels after Hirt's law in Balto-Slavic already, e.g. SCr. pitti 'to drink', píla '(she) drank' (with loss of the pretonic acute as a result of Meillet's law) of the root ${ }^{\star} p o H i-<$ PIE ${ }^{*}$ pe ${ }^{\text {wi }} i$.

(9) On the basis of these assumptions, Holzer reconstructs three accent paradigms, viz. a, which comprises (a) and (b), c, which is identical with (c), and $\mathbf{d}$, which is identical with (b) except in the nom.sg. form of the $o$ - and $s$-stems and is generally reflected as (c) in the historical languages. In this conception, the entire paradigm of ${ }^{*} z a m b a s$ became mobile under the influence of the sole nom.sg. form in ${ }^{*}$-as before this ending was replaced by ${ }^{*}-u$ in all Slavic languages. 
I shall not discuss the separate nominal paradigms, which can now be compared with my reconstructions (2008). Verbal paradigms are not homogeneous. While Holzer adduces SCr. viti 'to twist', which has an acute infinitive (a) but a mobile present and $l$-participle (c), he does not discuss gristi 'to bite' or sjëći 'to cut', which have an acute infinitive and l-participle (a) but a mobile present (c), or such verbs as péći 'to bake', which have an end-stressed infinitive and $l$-participle (b) but a mobile present (c), and lèci 'to lie down', which has an acute present (a) but an end-stressed infinitive and $l$-participle (b).

Adam Hyllested reconstructs an Indo-Uralic numeral 'one' with a medial ${ }^{\star} k$, e.g. in Finnish $y k s i$, which is reflected as a laryngeal ${ }^{\star} H$ in the acute of Lith. vienas. In his contribution to the present conference, Tijmen Pronk has shown that the acute must rather be explained from laryngeal metathesis in BaltoSlavic ${ }^{\star}$ Hino- (cf. also Derksen 2003).

Mate Kapović presents a most useful overview of the accentuation of $i$-verbs in Croatian dialects. While the accent paradigms (b) and (c) are often faithfully reflected in many dialects, there are a number of secondary developments which blur the picture. On the one hand, Stang's law did not operate before a clitic because it was limited to final syllables not counting final jers (cf. Kortlandt 2006a: 36). This resulted in such alternations as Ru. (Petr) kúrit vs. (vulkan) kuritsja 'smokes' and sádit vs. (solnce) saditsja 'sets', which led to a redistribution opposing transitive (b) to intransitive (c) verbs. On the other hand, the accent was retracted onto restored long root vowels in paradigm (c), which could then join paradigm (b). Both developments were already established by Carl Ebeling (1967: 593). Moreover, the distinction between simplex verbs with mobile stress (c) and compounds where Dybo's law shifted the stress from the prefix to the root so as to yield e.g. Kukljica ugäsin (a) and prebûdin (b) was mostly lost.

Apart from these secondary developments, the heterogeneous origin of the $i$-flexion must be taken into account. In my view, this class represents not only denominatives, which as a rule preserve the accent pattern of the underlying noun, as well as causatives and iteratives, which belong to accent pattern (b), but also athematic factitives and perfects, which belong to accent pattern (c) and may be compared with Latin capiō 'take' and sedeō 'sit' (cf. Kortlandt 1979: 59-62, 1987: 106-109, 1992, 2007a: 134-137, 2007b: 230). Kapović's data suggest that the original accentuation of the athematic $i$-flexion is best preserved in the čakavian and neo-štokavian dialects of southern Dalmatia and was lost in the northern dialects of Croatia.

Keith Langston reconsiders tone reversal in kajkavian dialects where original circumflex and neo-circumflex are rising while the neo-acute is falling, e.g. Vrbovec mẹso, tẹssto, mĩslim, sûša, pî̌sem, sẹla. He establishes the following relative chronology: 
(1) Circumflex stems advance the accent, e.g. mêso $>^{*} m e \bar{s} s \ddot{.}$

(2) Rising (neo-acute) accent becomes falling, e.g. kljũuč $>k l j u ̂ c ̌, ~ s \tilde{u} s ̌ a>s \hat{u} s ̌ a$, pĩšem > pî̌sem.

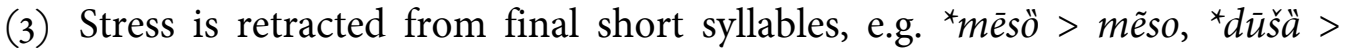
dũša.

It appears that short vowels behave in a similar way as long vowels in most of these dialects (but cf. Vermeer 1979: 366-377, Greenberg 2000: 105-112, Pronk 2007):

(1) pölje $>^{*}$ poljë, jägoda $>$ *jagodä.

(2) mlãtim $>$ mlâtim, mlãtimo $>$ mlâtimo.

(3) ${ }^{\star}$ poljë $>$ pòlje, ${ }^{\star}$ jagodä $>$ jagòda.

(4) lopäta > lòpata, pîtäti $>$ pĩtati, mlātïti $>$ mlãtiti.

(5) pòlje > pölje, jagòda > jagöda, lòpata > löpata.

(6) mlãtimo > mlätïmo in some dialects.

This account could be simplified by the assumption that the accent was retracted from an analogical neo-circumflex in *lopata > lopata at stage (4) of the chronology, which would eliminate the need to assume distinctive tone on short vowels at that stage. While Langston has clearly shown that the kajkavian development is different from other instances of tone reversal, the mechanism of accent shifts is strongly reminiscent of the way tonogenesis came about earlier and elsewhere in Baltic and Slavic (cf. Kortlandt 2006a: 36f., 2006b: 362f.).

Orsat Ligorio discusses the accent system of present-day Dubrovnik. In contrast to the literary language, this dialect has preserved original short vowels posttonically in sjëver 'north', djëver 'brother-in-law', jävor 'maple', nä bor beside bôr 'pine', pretonically in sùh $\bar{\imath}$ beside sûh 'dry', and under the stress in sëdmī '7th', ösmī '8th'.

Roman Sukač criticizes Kapović's recent articles about Proto-Slavic quantity. He observes a lack of chronological insight, failure to give proper credit to earlier investigators (Vondrák, Trávníček, Lamprecht), failure to see changes in a broader perspective, heavy reliance on his mother tongue and disregard of local developments elsewhere, and use of inappropriate examples (cf. also Kortlandt 2005). Perhaps most striking is the way Kapović suppresses the names of the greatest South Slavic dialectologists of the 2oth century, Aleksandar Belić (e.g., 1909) and Pavle Ivić (e.g., 1958).

The acute is not simply reflected as length in Czech because we find both long and short reflexes in the standard language and in the dialects, length being more frequent in the south-west and short reflexes predominating in the Moravian dialects. The original shortening of the acute can be identified with the rise of the new timbre distinctions. Short rising vowels were lengthened at a 
more recent stage in Czech, e.g. kráva, bláto, dial. krava, blato, also vůle, kůže, and Upper Sorbian, e.g. kruwa < krówa, błóto. This lengthening was regular in open first syllables of disyllabic word forms and blocked by a long vowel in the following syllable, e.g. kámen 'stone', gen.sg. kamene, lžice 'spoon', gen.pl. lžic, dat.pl. lžicím, psáti 'to write', spáti 'to sleep', preterit psal, spal (cf. Kortlandt 2005: 125).

The neo-acute is a heterogeneous category. The oldest long rising vowels arose at the end of my Early Middle Slavic period (6.10, cf. Kortlandt 2005: 119f., 2006a: 27), e.g. Slovak tráva 'grass', národ 'people', útroba 'intestines', also pýtat' $s a$ 'to inquire', miešat 'to blend', stúpat 'to mount'. These vowels remained long when they lost the stress to the following syllable in accordance with Dybo's law (8.7). More recent long rising vowels arose from the retraction of the stress from final jers (8.2), e.g. gen.pl. nôh 'feet', rúk 'hands', also niesol 'carried' < ${ }^{*} n e s l b$, 2nd sg. nesieš $<{ }^{*} n e s e s ̌ b$, from the retraction of the stress from long falling vowels in final syllables (Stang's law, 9.3), e.g. vôla 'will', 2nd sg. môžeš 'can', pôjdeš 'will go', also pýtaš, miešaš, stúpaš (cf. Kortlandt 2006a: 35), from the retraction of the stress from non-final jers (10.3), e.g. rúčka 'penholder', dcérka 'little daughter', and from the lengthening of short rising vowels in Czech kráva and Upper Sorbian kruwa (10.6). Other long vowels developed from compensatory lengthening after the loss of final jers, e.g. Czech bưh 'god', diom 'house', kưn 'horse', nuż 'knife'.

Original (pre-Dybo) pretonic long vowels were shortened when the new timbre distinctions arose (7.13), e.g. SCr. jèzik, màlina, ràkita, dalèko, svjèdok, dùžnīk, glàdnī, gràdskī, rùkama, rùčnì, rùčnìk, hlàdnī, tèškī, mùškī, gùstī, svètī,

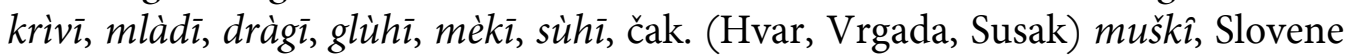
mehkî, Czech chladný, těžký, suchý, ruka, ruční, ručník, humno, sukno, Polish sędzia (cf. Kortlandt 2005: 126f., 2006a: 36f.). Long vowels which became pretonic as a result of Dybo's law (8.7) remained long, e.g. SCr. národ, rázlika, zábava, tráva, trâvnī, trâvnīk, bêlì, pûtnīk, Czech bílý, poutník, tráva, trávní, trávník, zábava, útroba, Polish wątroba. The long vowels of Czech plátno 'linen', vlákno 'fibre', Slovak súkno 'cloth' were taken from the plural (cf. Kortlandt 2005: 127). Posttonic long vowels were usually preserved in Proto-Slavic (cf. Kortlandt 2005: 128f.).

I conclude that the Leiden conference was a great success. Since both Georg Holzer and Roman Sukač have offered to host future conferences on BaltoSlavic accentology, we can be sure that this important forum of discussion will be continued in the years to come.

Leiden University 


\section{REFERENCES}

Belić, Aleksandar

1909 “Zamětki po čakavskim govoram”. Izvěstija Otdělenija russkago jazyka $i$ slovesnosti 14/2, 181-266.

Derksen, Rick

2003 "Slavic ${ }^{\star}{ }_{j b}$-". In: Jos Schaeken, Peter Houtzagers, Janneke Kalsbeek (eds.), Dutch contributions to the Thirteenth International Congress of Slavists, Ljubljana: Linguistics (Studies in Slavic and General Linguistics 30), 97-105. Amsterdam-New York: Rodopi.

Ebeling, Carl L.

1967 "Historical laws of Slavic accentuation". In: To honor Roman Jakobson 1, 577-593. The Hague: Mouton.

Greenberg, Marc L.

$2000 \quad$ A historical phonology of the Slovene language. Heidelberg: Universitätsverlag. Illič-Svityč, Vladislav M.

1963 Imennaja akcentuacija v baltijskom i slavjanskom. Moskva: AN SSSR.

Ivić, Pavle

1958 Die serbokroatischen Dialekte. The Hague: Mouton.

Kortlandt, Frederik

1974 “Old Prussian accentuation”. Zeitschrift für vergleichende Sprachforschung 88, 299-306.

1978 “A history of Slavic accentuation". Lingua 44, 67-91.

1979 "Toward a reconstruction of the Balto-Slavic verbal system". Lingua 49, 51-70.

1985 "Slavic imamb". International Journal of Slavic Linguistics and Poetics 31-32, 235-239.

1986 “Proto-Indo-European tones?". Journal of Indo-European Studies 14, 153-160.

1987 "The formation of the Old Prussian present tense". Baltistica 23/2, 104-111.

1992 "Le statif indo-européen en slave". Revue des Études Slaves 64, 373-376.

1993 "The origin of the Japanese and Korean accent systems". Acta Linguistica Hafniensia 26, 57-65.

2005 "From Serbo-Croatian to Indo-European". Wiener slavistisches Jahrbuch 51, 113-130.

2006a "On the relative chronology of Slavic accentual developments". Wiener slavistisches Jahrbuch 52, 25-41.

2006 b "Balto-Slavic accentual mobility". Baltistica 41/3, 359-369.

2007a Italo-Celtic origins and prehistoric development of the Irish language (Leiden Studies in Indo-European 14). Amsterdam-New York: Rodopi.

$2007 \mathrm{~b}$ "Miscellaneous remarks on Balto-Slavic accentuation". In: Mate Kapović and Ranko Matasović (eds.), Tones and theories: Proceedings of the International Workshop on Balto-Slavic Accentology, 229-235. Zagreb: Institut za hrvatski jezik i jezikoslovlje.

2008 "Slavic historical morphology: Nominal paradigms". In: Peter Houtzagers, Janneke Kalsbeek, Jos Schaeken (eds.), Dutch contributions to the Fourteenth International Congress of Slavists, Ohrid: Linguistics (Studies in Slavic and General Linguistics oo), ooo-ooo. Amsterdam-New York: Rodopi.

Pronk, Tijmen

2007

"The retraction of the neocircumflex in the Carinthian dialects of Slovene (on Ivšić's retraction)". In: Mate Kapović and Ranko Matasović (eds.), Tones and 
theories: Proceedings of the International Workshop on Balto-Slavic AccentolVermeer, Willem R. ogy, 171-183. Zagreb: Institut za hrvatski jezik i jezikoslovlje.

1979

"Innovations in the kajkavian dialect of Bednja". In: Jan. M. Meijer (ed.), Dutch contributions to the Eighth International Congress of Slavists, Zagreb, Ljubljana, 347-381. Lisse: Peter de Ridder. 